\title{
Analysis of growth and physicochemical changes in apple cv. Anna in a high-altitude tropical climate
}

\section{Análisis de crecimiento y cambios fisicoquímicos del fruto de manzana cv. Anna en clima de trópico alto}
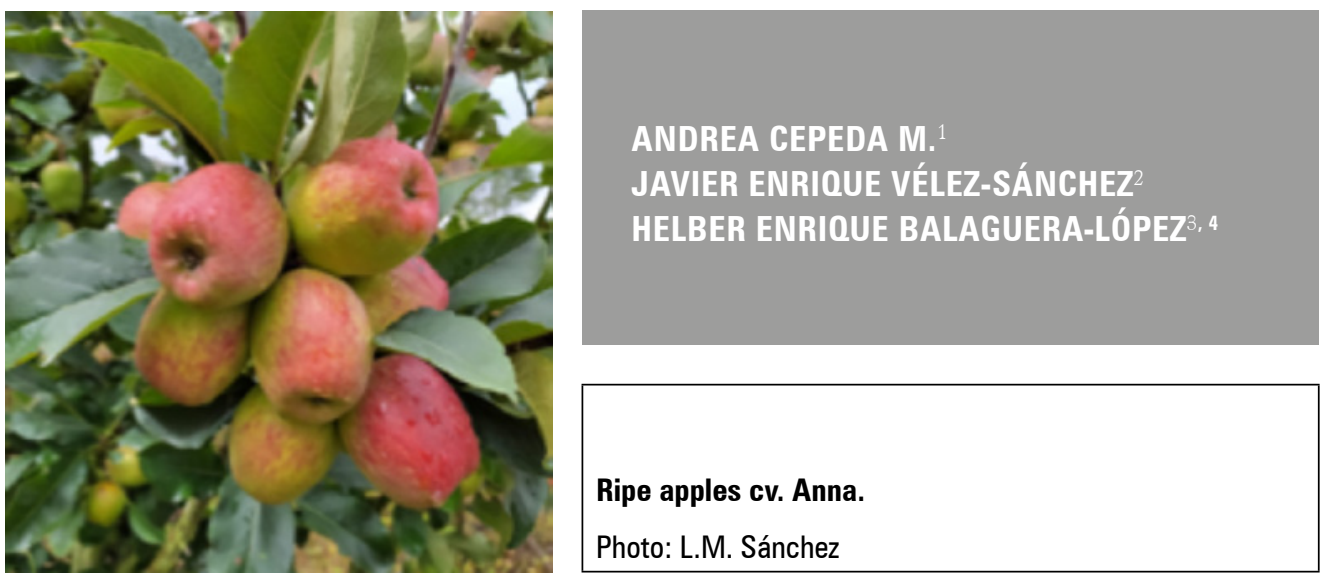

\begin{abstract}
The objective of this research was to carry out an analysis of growth and physicochemical changes in cv. Anna apple in the Colombian high-altitude tropics using on the accumulation of growing degree days (GDD). Fruit samplings were taken every 15 days after anthesis (DAA) until harvest at 100 DAA (892.37 GDD). The dry and fresh weight and the equatorial and polar diameters followed a simple sigmoidal pattern. This was confirmed with the behavior of the growth rates. The equatorial and polar diameters increased drastically between 455.39 and $589.32 \mathrm{GDD}$ (45 and $60 \mathrm{DAA}$ ), while the weight did not, indicating that the void spaces increased in the pulp during this period. The respiratory rate had the highest value $\left(61.93 \pm 6.79 \mathrm{mg} \mathrm{CO} \mathrm{kg}^{-1}\right.$ $\left.\mathrm{h}^{-1}\right)$ at 159.61 GDD (15 DAA) and then decreased continuously until harvest. The firmness increased from 159.61 to $455.39 \mathrm{GDD}$ and, then continuously decreased, at harvest, it was $38.38 \pm 3.48 \mathrm{~N}$. The total soluble solids increased and had an ending value of $8.58 \pm 0.37^{\circ} \mathrm{Brix}$. The total titratable acidity increased from 159.61 to $319.79 \mathrm{GDD}$ (30 DAA), and then decreased until the end of the study with an acidity of $0.71 \pm 0.03 \%$. The color index increased linearly as a function of development, but the values were $<0$ at harvest. These results are an important advance for knowledge on the behavior of apple cv. Anna under high-altitude tropical conditions.
\end{abstract}

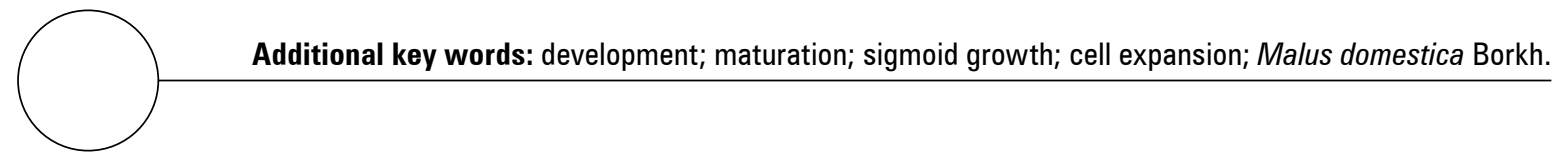

Universidad Pedagógica y Tecnológica de Colombia, Programa de Maestría en Fisiología Vegetal, Tunja (Colombia). ORCID Cepeda M., A.: 0000-0002-0675-1601

2 Universidad Nacional de Colombia, Facultad de Ingeniería, Departamento de Ingeniería Civil y Agrícola, Bogota (Colombia). ORCID Vélez-Sánchez, J.E.: 0000-0002-1361-8374

3 Universidad Nacional de Colombia, Facultad Ciencias Agrarias, Departamento de Agronomía, Bogota (Colombia). ORCID Balaguera-López, H.E.:0000-0003-3133-0355

4 Autor para correspondencia.hebalagueral@unal.edu.co 


\section{RESUMEN}

El objetivo fue realizar el análisis de crecimiento y de los cambios fisicoquímicos del fruto de manzana cv. Anna en trópico alto colombiano en función de la acumulación de grados día de crecimiento (GDC). Se hicieron muestreos de frutos cada 15 días después de antesis (DDA) y hasta la cosecha a los 100 días (892,37 GDC). El peso fresco y seco y el diámetro ecuatorial y polar siguieron un patrón sigmoide simple, esto se corroboró con el comportamiento de las tasas de crecimiento. El diámetro ecuatorial y polar aumentaron drásticamente entre los 455,39 y 589,32 GDC (45 y $60 \mathrm{dda}$ ), mientras que las masas no, indicando que en este periodo se incrementan los espacios vacíos en la pulpa. La tasa respiratoria tuvo el mayor valor $\left(61.93 \pm 6.79 \mathrm{mg} \mathrm{CO}_{2} \mathrm{~kg}^{-1} \mathrm{~h}^{-1}\right)$ a los 159,61 GDC (15 DDA) y luego disminuyó de forma continua hasta la cosecha. La firmeza aumentó de los 159,61 GDC a los 455,39 GDC, luego fue decreciendo continuamente y en la cosecha fue de $38.38 \pm 3.48 \mathrm{~N}$. Los sólidos solubles totales incrementaron y al final presentaron un valor de $8,58 \pm 0,37^{\circ} \mathrm{Brix}$. La acidez total titulable incrementó de los 159,61 GDC a los 319,79 GDC (30 DDA), para luego disminuir hasta el final del estudio, momento en el que presentó una acidez de $0.71 \pm 0.03 \%$. El índice de color aumentó de forma lineal en función del desarrollo, pero en la cosecha los valores fueron $<0$. Estos resultados son un avance importante hacia el conocimiento del comportamiento del fruto de manzana cv Anna en condiciones tropicales.

Palabras clave adicionales: desarrollo; maduración; crecimiento sigmoide; expansión celular; Malus domestica Borkh.

Received: 22-02-2021 Accepted: 28-02-2021 Published: 21-03-2021

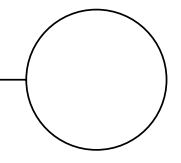

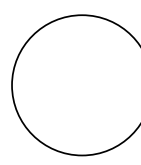

Apples have high economic and nutritional value and are grown in many countries. The Department of Boyaca is important in the exploitation of deciduous crops in Colombia, including apples, japanese plums, peaches and pears, mainly because of the edaphoclimatic conditions of this department (Puentes et al., 2008; Orduz-Rios et al., 2020; Casierra-Posada et al., 2017). However, domestic apple production is well below national demand, resulting in large import volumes of apples from Chile. According to Puentes et al. (2008), the fundamental cause of problems in deciduous fruit trees in Colombia lies in the lack of cultivation planning. Mainly because the development of these fruit trees in the tropics is affected by the absence of chilling temperatures and long days (Fischer, 2013). However, there have been important advances in the use of new varieties with low chilling requirements and easy acclimatization to high-altitude tropics. Therefore, the study of deciduous fruit trees under tropical conditions is important for understanding the behavior of established varieties production factors that are necessary for each location to achieve good crop management (Puentes et al., 2008).

The most important apple variety in Colombia is Anna. It requires $300-400$ chilling hours. The epidermis has red stripes where it receives sunlight and a yellow color on the other side. The pulp is creamy white with a medium texture and a sweet acid flavor. The fruit is medium-sized and has an elongated shape. In Colombia, two harvests are possible in areas with a bimodal precipitation regimen (Campos, 2013). However, there are few studies for this variety.

The growth and development of fruits are processes with biological and commercial importance (Malladi, 2020) that, must be modeled to design management strategies for apple orchards (Hester and Cacho, 2003). However, there are no recent scientific reports on the growth and development of apples in Colombia. This information would provide objective management recommendations for pruning, fruit thinning, fertilization, irrigation, harvesting, and other factors. One of the few studies available was conducted by Casierra-Posada et al. (2003), who reported results of a basic analysis of the growth of apples cv. Anna under the climatic conditions of Paipa, Boyaca by determining the weight and diameter of fruits and concluding that this fruit has a simple sigmoid growth curve. Likewise, Atay et al. (2010) reported that the growth of apples in temperate zones also follows a simple sigmoid pattern. However, Magein (1989) found that the growth of apples follows a double sigmoid curve, with a slow growth phase, attributed more to changes in the physiology of trees than to the physiology of fruits. In the world, new apple cultivars have 
been released that are adapted to a range of weather conditions. Some research has been conducted with respect to adaptation to local weather conditions and a few non-mathematical models have been developed (Chaves et al., 2017).

The apple is largely derived from non-ovarian tissues. Therefore, the regulation of fruit growth in apples is probably different from that of other models of fleshy fruit species. Fruit growth is an integration of multiple processes that are regulated through developmental factors, phytohormones, and the availability of metabolic resources (Malladi, 2020). These factors influence growth in different ways during the various stages of development and in the different tissues (Malladi, 2020). Nowadays, fruit quality is one of the main concerns of consumers (Fathizadeh et al., 2021). Quality depends to a large extent on the optimal harvest time of apples, which is derived from knowledge on the behavior of growth parameters. During ripening, there are changes in color, reductions in firmness and starch content, increases in soluble sugars, and decreases in acidity (Costa et al., 2010; Jing and Malladi, 2020). For example, the sugar content in apples is related to the development of the fruit (Zhang et al., 2015). Organic acids decrease as the fruit matures, and in combination with sugars and volatile compounds, determine flavor (Liu et al., 2016).

Therefore, the objective of this research was to analyze the growth and the main physicochemical changes in apple (Malus domestica Borkh) cv. Anna under conditions of a tropical cold climate at high altitudes.

\section{MATERIALS AND METHODS}

This study was carried out in a commercial orchard of deciduous fruit trees on the "Tunguavita" farm of the Universidad Pedagógica y Tecnológica de Colombia (UPTC), municipality of Paipa (Boyaca - Colombia), between March and June of 2016. Tis farm is located at $5^{\circ} 45^{\prime} \mathrm{N}$ and $73^{\circ} 45, \mathrm{~W}$, at 2,525 $\mathrm{m}$ a.s.l. Climatic conditions during the experiment are presented in table 1 . The laboratory phase was carried out in the plant physiology laboratory of the Faculty of Agricultural Sciences of the same university.

Twenty apple trees (Malus domestica Borkh) cv. Anna (Golden Delicious XAdassim Red) on MM106 rootstock, approximately 5-7 years old, planted at distances of $2 \mathrm{~m}$ between plants and $3 \mathrm{~m}$ between rows,
Table 1. Temperature and precipitation during the experiment.

\begin{tabular}{|l|c|c|c|c|}
\hline Month & $\begin{array}{c}\text { Minimum } \\
\left({ }^{\circ} \mathrm{C}\right)\end{array}$ & $\begin{array}{c}\text { Maximum } \\
\left({ }^{\circ} \mathrm{C}\right)\end{array}$ & $\begin{array}{c}\text { Mean } \\
\left({ }^{\circ} \mathrm{C}\right)\end{array}$ & $\begin{array}{c}\text { Precipitation } \\
(\mathrm{mm})\end{array}$ \\
\hline March & 7.7 & 26.0 & 16.9 & 34.6 \\
\hline April & 10.4 & 23.0 & 16.7 & 197.5 \\
\hline May & 8.8 & 22.1 & 15.5 & 112.7 \\
\hline June & 6.9 & 21.2 & 14.1 & 25.7 \\
\hline
\end{tabular}

and with production pruning were selected. The trees were trained to a central leader system, without fruit thinning. They were fertilized with mineral nutrients and organic matter according to the recommendations for the zone and based on soil analysis, and apple trees were supplemented with foliar fertilization. Drip irrigation water at regular intervals in the vegetation period with four drippers/tree of $8 \mathrm{~L}$ $\mathrm{h}^{-1}$ was used. Approximately 200 fruits were collected from initial flowers from each of the trees, which were previously marked in the anthesis stage. Harvesting of the fruits was done randomly from day 15 after anthesis (DAA) and every 15 days until harvest. Equation 1 was used to calculate growing degree days (GDD):

$G D D=(\operatorname{Tmax}+T \min ) / 2)-$ Tbase

where Tmax and Tmin are, respectively, maximum and minimum daily air temperatures, and Tbase is the temperature at which the metabolic process in apples is at its lowest point, which was assumed as $7.22^{\circ} \mathrm{C}$ according to Chaves et al. (2017).

The following variables were determined in each of the samplings. The fresh weight was determined with a precision balance with an approximation of $0.01 \mathrm{~g}$. Dry weight was determined by leaving the fruits in a muffle furnace at $75^{\circ} \mathrm{C}$ until a constant weight was obtained. The absolute growth rate (AGR) and relative growth rate (RGR) of dry weight were calculated following the methodology of Ochoa-Vargas et al. (2016). The polar diameter and equatorial diameter were determined with a $0.01 \mathrm{~mm}$ digital caliper.

To determine the respiration rate $\left(\mathrm{mg} \mathrm{CO}_{2} \mathrm{~kg}^{-1} \mathrm{~h}^{-1}\right)$, approximately $200 \mathrm{~g}$ of fruits were sealed in a $2 \mathrm{~L}$ hermetic chambers containing an infrared $\mathrm{CO}_{2}$ sensor. This was connected to an interface system (Labquest 1), and data was recorded every $5 \mathrm{~s}$ for $5 \mathrm{~min}$ (AfricanoPérez et al., 2016). 
The fruit firmness $(\mathrm{N})$ was obtained by using a PCEPTR200 digital penetrometer with an approximation of $0.05 \mathrm{~N}$. The color index of epidermis (background color) and pulp was calculated with equation 2 using the measurement of the $L^{*}, a^{*}$ and $b^{*}$ parameters with a CR 410 digital colorimeter (Konica Minolta brand, Hong Kong):

$$
C=\frac{1,000 x a^{*}}{L^{*} x b^{*}}
$$

The total soluble solids (TSS) were measured with a Hanna brand digital refractometer at a precision of $0.1^{\circ} \mathrm{Brix}$. The total titratable acidity (TTA, \% malic acid) was obtained with acid-base titration according to Mariño-González et al. (2019).

The data were presented as the mean \pm standard error from 10 repetitions for the physical variables, each repetition composed of a fruit, while four repetitions were used for the chemical determinations. The behavior of each variable with respect to thermal time was plotted and the statistical models with the best fit were determined. The growth curves and rates were obtained with functional analysis, following the methodology used by Ochoa-Vargas et al. (2016) with SAS v. 9.2e (Cary, N.C).

\section{RESULTS AND DISCUSSION}

\section{Growth analysis}

Dry weight and growth rates: The apple fruits had a simple sigmoid type growth explained by a logistic growth model (Fig. 1; Tab. 2). Three growth phases were identified; in the first phase a slow growth was observed up to $159.61 \mathrm{GDD}$ (30 DAA). At this point, the fruits gained in dry weight $0.732 \pm 0.026 \mathrm{~g}$, and there was a stage of rapid growth that ended at 823.59 GDD (90 DAA); at which point, the fruits increased in dry matter $8.56 \pm 0.443 \mathrm{~g}$. Finally, the ripening phase ended with the harvest at 892.37 GDD (100 DAA), where the growth was less with a gain in dry weight of $9.72 \pm 0.358 \mathrm{~g}$. Casierra-Posada et al. (2003) found that development of the 'Anna' apple fruit lasted 120 days in the region. This longer duration could mainly be due to differences in climate; these authors reported $13.8^{\circ} \mathrm{C}$, but in our study, the mean temperature was $2^{\circ} \mathrm{C}$ higher (Tab. 1).

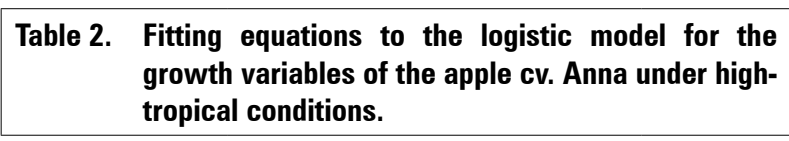

\begin{tabular}{|c|c|c|}
\hline Parameter & Equations & $R^{2}$ \\
\hline $\begin{array}{l}\text { Dry weight of } \\
\text { the fruit }\end{array}$ & $Y=11.274 / 1+e^{-0.007471^{*}(G D D-657.89)}$ & $0.9988 * *$ \\
\hline Fresh fruit weight & $Y=78.669 / 1+e^{-0.0073213^{*}(G D D-651.6)}$ & $0.9979 * *$ \\
\hline Polar diameter & $Y=55.758 / 1+e^{-0.0317977^{*}(G D D-535.426)}$ & $0.9912^{* *}$ \\
\hline $\begin{array}{l}\text { Equatorial } \\
\text { diameter }\end{array}$ & $Y=48.6469 / 1+e^{-0.02576^{*}(G D D-350.259)}$ & $0.9913^{* *}$ \\
\hline
\end{tabular}

** Significant models $(P \leq 0.01)$.

The growth rates confirmed the simple sigmoid behavior since, in the first phase, the AGR had a slow rise with a value for 319.79 GDD of $0.0069 \mathrm{~g}$ per GDD, and the RGR had a slow decrease at this same point of $0.0058 \mathrm{~g} \mathrm{~g}^{-1}$ per GDD; then, in the rapid growth phase, the AGR increased rapidly, reached its maximum value at $654.91 \mathrm{GDD}$ with a value of $0.0211 \mathrm{~g}$ per GDD and then decreased. The RGR had a rapid decrease for this same point, which confirmed the rapid gain in dry weight in the second phase. In the maturation stage, the AGR showed a rapid decrease with a value at 892.37 GDD of $0.011 \mathrm{~g}$ per GDD and the RGR showed a value at that same point of 0.0011 $\mathrm{g} \mathrm{g}^{-1}$ per GDD, indicating the lowest rate accumulation of dry weight during the ripening phase (Fig. 1B). This means that the maximum growth rate occurred in the second stage of development. This agrees with that observed in lulo fruits (Almanza-Merchán et al., 2016), pears (Molina-Ochoa et al., 2016) and Ultra Red Gala apples (Yuri et al., 2011). In this latter study, the AGR and RGR had similar trends to those found in cV. Anna, with the difference that, in the first growth phase, these rates indicated a higher growth speed in Ultra Red Gala apples.

The fresh fruit weight was also described by a logistic model with the simple sigmoid pattern (Fig. 2A; Tab. 2). Three phases of fruit growth were identified. In the first phase up to 319.79 GDD, a slow growth was observed; at this point, the fruits accumulated $5.865 \pm 0.169 \mathrm{~g}$ of fresh weight. In the second phase an increase in growth speed was observed up to 823.59 GDD (90 DAA) with a fresh weight gain of $63.664 \pm 3.394$ g. For the third growth phase, which 

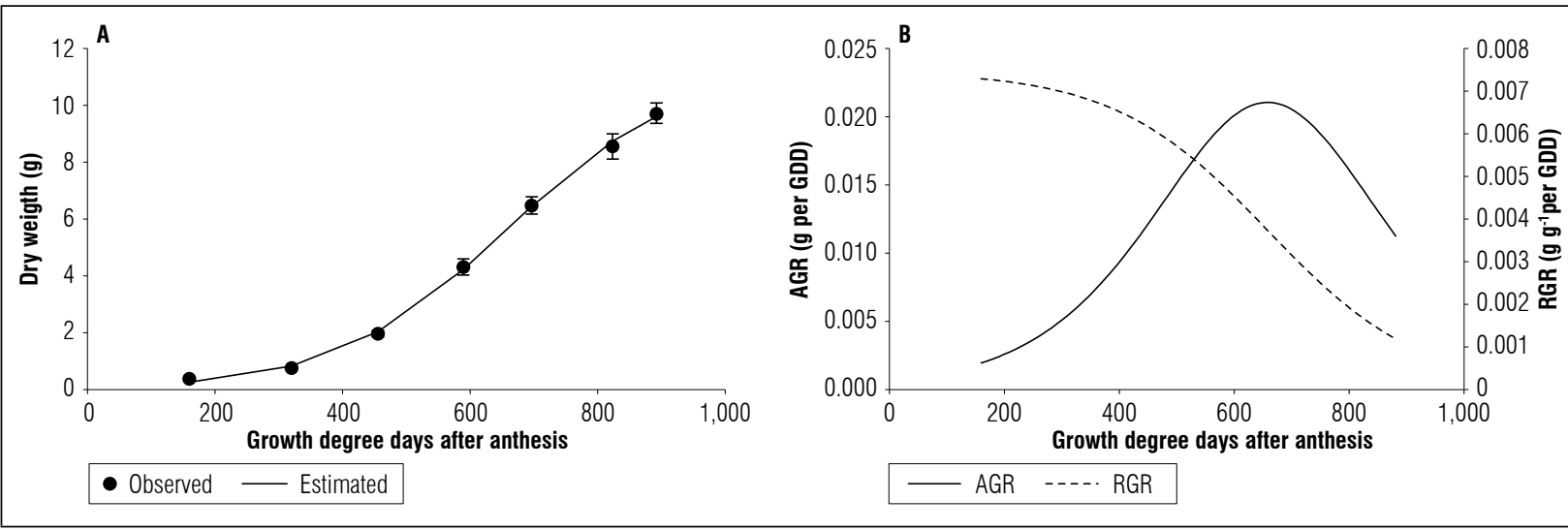

Figure 1. Behavior of A. Dry weight, B. Absolute growth rate (AGR) and Relative growth rate (RGR) of apples cv. Anna under high altitude tropical conditions. The vertical bars in figure $1 A$ indicate the standard error $(n=10)$.

culminated with the fruit harvest, the growth slowly decreased to 892.37 GDD with a fresh weight gain of $66.088 \pm 2.544 \mathrm{~g}$.

In Ultra Red Gala apples, growth was also simple sigmoid but was adjusted to a Gompertz model (Yuri et al., 2011), while 'Anna' was adjusted to a polynomial regression (Casierra-Posada et al., 2003). The simple sigmoid type growth found in cv. Anna for dry and fresh weight is a manifestation of the three growth periods of apples: a first period of intense cell production; a second period of cell elongation, the vacuoles increase in size and starch, organic acids, sugars and other components begin to accumulate; and the last phase has the highest growth speed (Malladi, 2020), with a final maturation phase, where the maximum accumulation of weight is reached.

Photosynthesis plays a fundamental role in dry weight gain because of the translocation of photoassimilates from other plant parts to fruits. This remobilization of photoassimilates corresponds to between 40 and $50 \%$ of the weight of fruits as reported for mango (Castro Neto and Reinhardt, 2003). However, it is a process that largely depends on the sink activity of fruits, which is influenced by the hormonal synthesis of seeds (Balaguera-López et al., 2020). In apples, miR172 has been associated with the regulation of growth and final fruit size (Yao et al., 2015). Lower miR172 levels were associated with increased fruit growth; for this reason, overexpression of miR172p (one of several active miR172s) in transgenic 'Royal Gala' plants results in a representative reduction in fruit size (Yao et al.,
2015). The same authors suggested that the basal regions of floral organs, particularly sepals, contribute greatly to the development of major fleshy tissues of the apples.

Monitoring fruit growth and apple size is important for several reasons: prediction of potential fruit size and yield, as well as for use in crop simulation models (Zadravec et al., 2013). Early prediction models combine fruit counts and size measurements with precalculated growth curves and correlations between fruit diameter and weight (Wulfsohn et al., 2012). In addition, the models establish agronomic practices such as fertilization, irrigation, thinning, pruning, among other reasons.

The polar diameter was fitted to a logistic model. During the first 455.39 GDD (45 DAA), the increase was not very representative, and the fruits reached $3.659 \pm 0.0593 \mathrm{~mm}$. From $455.39 \mathrm{GDD}$, there was a marked increase in diameter up to 589.32 GDD (60 DAA), at which point the diameter was $47.622 \pm 1.4351 \mathrm{~mm}$. An increase in this parameter was still monitored until harvest, when the fruits reached $59.5 \pm 0.9409 \mathrm{~mm}$ (Fig. 2B; Tab. 2). The equatorial diameter at the time of harvest was $52.393 \pm 1.4351$ $\mathrm{mm}$ and was similar to the polar diameter (Fig. 2C; Tab. 2), but was always smaller, an indication of the characteristic shape of the fruit of this cultivar, which tends to be an elongated fruit because of the tropical high altitudinal conditions. The values of the diameters were notably lower than those reported for varieties such as Golden Delicious Reinders and Fuji Kiku 8 (Zadravec et al., 2013). These same authors indicated that these discrepancies in fruit diameter and 


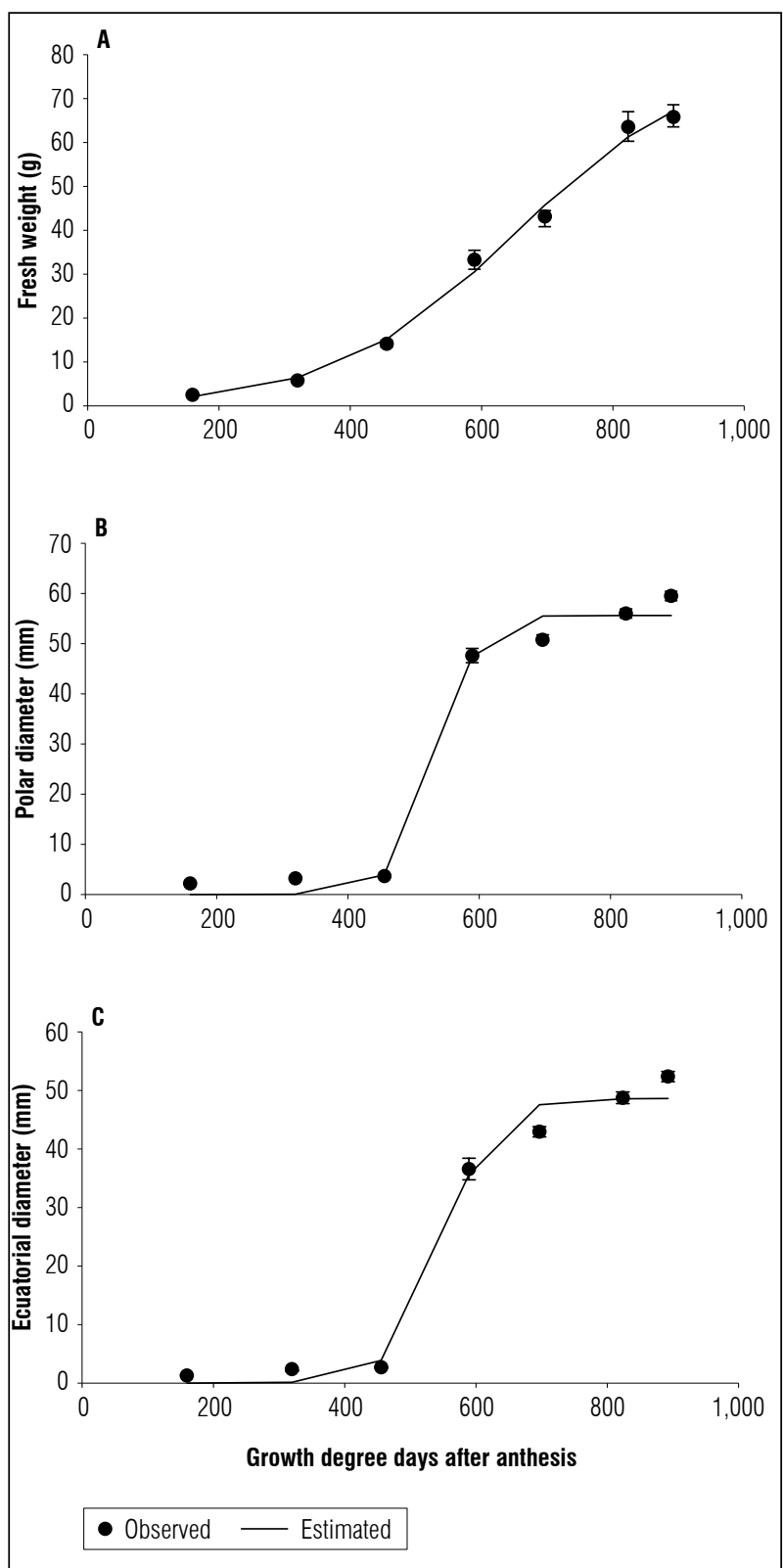

Figure 2. Behavior of A. Fresh weight, B. Polar diameter and C. Equatorial diameter of apples cv. Anna under conditions high-altitude tropics. The vertical bars at each mean indicate the standard error $(n=10)$.

weight can be explained by genetic factors (cultivars, strains) location, and dependence on environmental conditions.

The increase in the two diameters from 455.39 to 589.32 GDD was abrupt, while, in the fresh and dry weights, this increase was not so marked. This was perhaps due to the fact that the fruits increased the void spaces in the pulp in the expansion phase. This is a phenomenon that occurs in apples and can determine fruit firmness (Saei et al., 2011). The development of void spaces is one of the three main processes that determines growth, along with cell production and expansion. However, the development of void spaces remains a little known process despite its relatively significant contribution to the final size of fruits (Malladi, 2020).

\section{Physicochemical behavior of fruits}

The respiratory rates showed a continuous decrease during the development of the fruits, whose behavior was adjusted to a second degree polynomial. At 159.61 GDD, there was a respiratory rate of $61.93 \pm 6.79 \mathrm{mg}$ $\mathrm{CO}_{2} \mathrm{~kg}^{-1} \mathrm{~h}^{-1}$ corresponding to the fruit formation phase. At 892.37 GDD, the lowest rate corresponded to the physiological maturity phase, $4.23 \pm 0.16 \mathrm{mg}$ $\mathrm{CO}_{2} \mathrm{~kg}^{-1} \mathrm{~h}^{-1}$ (Fig. 3A).

In the first phase of fruit development, at high respiratory rate supplies the energy requirements for the cell division process, a process that determines the relative rate of cell production and reaches a maximum of around 0.26 cells per cell per day during the initial period of fruit growth in apple (Dash et al., 2012). Hexokinase activity and the abundance of hexokinase gene transcripts is higher during early fruit growth (Li et al., 2012). This flow towards glycolysis and subsequent respiration is essential to meeting the demands for energy and carbon skeletons in this phase of development (Malladi, 2020). The glycolytic flow is high during the early development of fruits (Beshir et al., 2017) and decreases in later stages (Li et al., 2016), which explains the respiratory behavior obtained in the cv. Anna.

Respiratory intensity is a good physiological index to determine fruit harvest; when the respiration rate reaches its minimum level, fruits are in full development. This behavior could be observed in apples; as fruit growth increases, a decrease in respiration is seen. The apple fruit reached physiological maturity at 892.37 GDD. At this point, the lowest respiratory rate occurred when the fruits were physiologically ready to be harvested.

The behavior of the firmness was characterized by an increase in the first $455.39 \mathrm{GDD}$, when a value of $62.19 \pm 1.76 \mathrm{~N}$ was obtained, then a very marked decrease up to $823.59 \mathrm{GDD}$ with a value of $41.16 \pm 2.43$ 


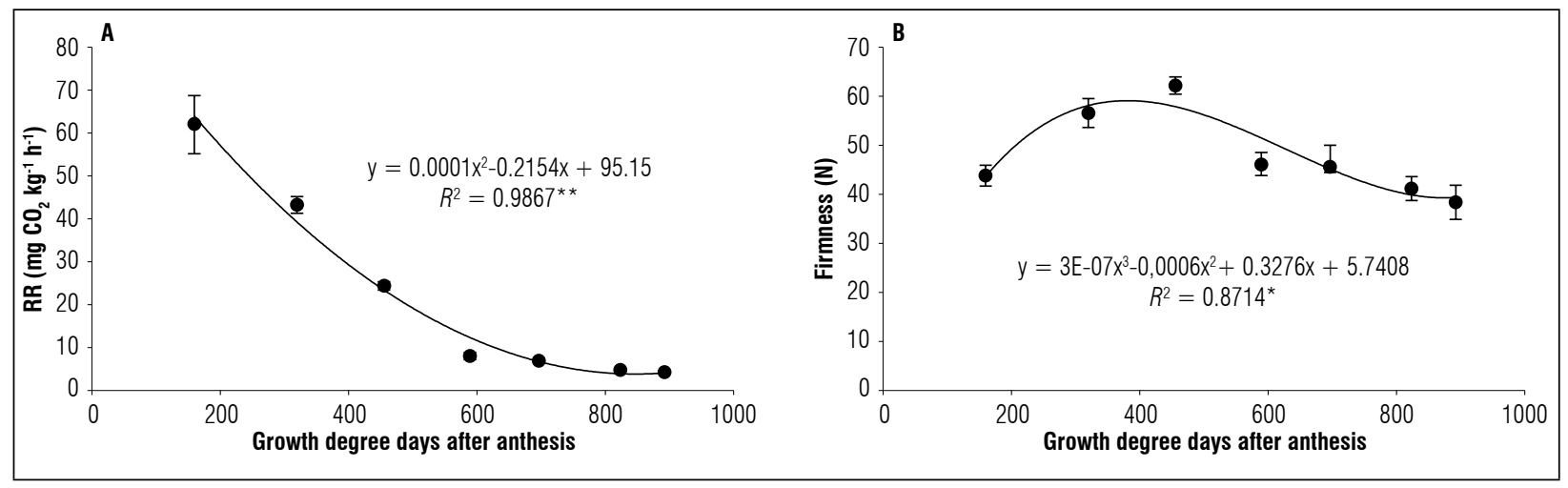

Figure 3. Behavior of A. Respiratory rate and B. Firmness of apples cv. Anna under conditions in high-altitude tropics. The vertical bars in each mean indicate the standard error $(n=4)$.

$\mathrm{N}$, with a gradual decrease up to 892.37 GDD with a value of $38.38 \pm 3.48 \mathrm{~N}$, which adjusted to a thirddegree polynomial (Fig. 3B). Firmness is a primary measure of apple fruit texture and is the key determinant of eating quality for apples. There is very limited information of firmness in pre-harvest and at harvest. These are causes of variations in fruit quality in the marketplace (Saei et al., 2011). These same authors reported that firmness in the apples depends on variation in the strength of the tissue caused by differences in the size of the cells, the number of cells, the intercellular air space, and the material of the cell wall per unit volume of the fruit.

The increase in firmness that is observed in apples in the first growth phase, also observed in araza, may be associated with the synthesis of protopectin (Hernández et al., 2007). For the second growth phase of the apples, a decrease in firmness was seen. The decrease in the firmness of the fruits coincides with the dissolution or hydrolysis of the middle lamina and cell wall, resulting in a reduction in intercellular adhesion, depolymerization, and solubilization of hemicellulosic and pectic polysaccharides of the cell wall (Morais et al., 2008). Alterations in cell turgor and the degradation of starch reserves also lead to a loss of firmness (Kays, 2004). Similarly, in apples cv. Fuji, the highest firmness values occur between 30 and 58 days after flowering, with a continuous decrease until harvest (Sha et al., 2020).

The background color index of the epidermis increased as a function of time, going from a value of $-7.99 \pm 0.1$ at $159.61 \mathrm{GDD}$ to $-5.12 \pm 0.29$ at 892.37 GDD. The color index of the pulp also increased throughout the development of the fruit, from a value of $-5.61 \pm 0.293$ at $159.61 \mathrm{GDD}$ to $-3.311 \pm 0.317$ at 892.37 GDD (Fig. 4).

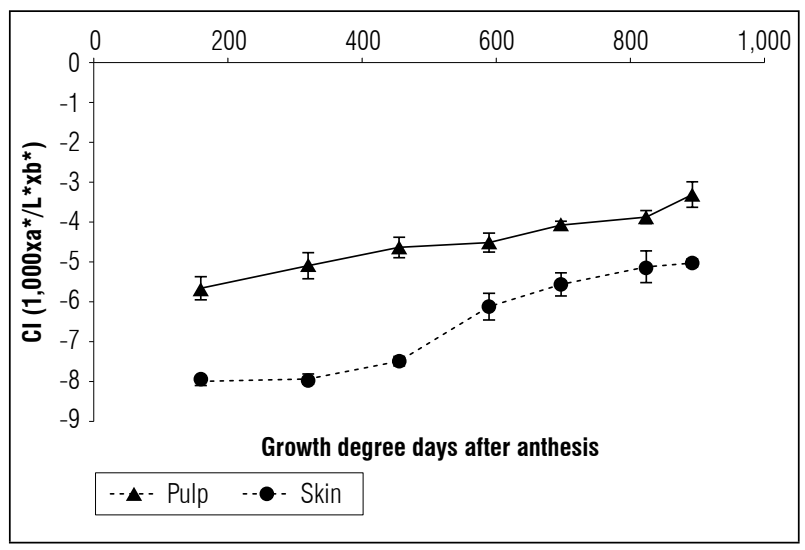

Figure 4. Behavior of the color index of the epidermis and pulp in apples cv. Anna under conditions in highaltitude tropics. The vertical bars in each mean indicate the standard error $(n=10)$.

The epidermis of the fruit is red where it receives sunlight and yellow on the opposite side (Campos, 2013). The background color was measured since the red color of the coating is not a good indicator of ripening. The results indicated that, as fruits progress in development, the coloration of both the epidermis and the pulp increased linearly with respect to time. However, the values of the epidermis were below zero at harvest, indicating that they were still green. At postharvest, they can acquire yellow atonalities, although they are sometimes very weak, indicating that this cultivar has coloration problems, mainly because of environmental factors. This is a commercial 
limitation because yellow coloration is not attractive to consumers. In this regard, the color of the fruits is an important contribution for health and economic benefits (Zhu et al., 2019), influencing sales and acceptance by consumers (Iglesias et al., 2012). Finding solutions to improve the color of the Anna cultivar should be a priority to make these fruits more competitive that imported apples.

In apples, a color change is due to the degradation of chlorophylls and the synthesis of anthocyanins. The latter are dependent on light for their production (Iglesias et al., 2012), and can be affected by factors such as temperature, state maturity, and cultivars (Lin-Wang et al., 2011; Iglesias et al., 2012). This indicates that, in addition to genetics, ecophysiological factors are of great importance to attractive colorations in cv. Anna fruits. Cool nights are recommended prior to harvest since high temperatures can inhibit anthocyanin synthesis (Lancaster, 1992). Achieving an optimal skin color in apples is usually a problem in most southern European countries (Iglesias et al. 2012).

The total soluble solids increased linearly as a function of time: at $159.61 \mathrm{GDD}$, they had a value of $5.5 \pm 0.35^{\circ}$ Brix at $589.32 \mathrm{GDD}$ a value of $6.975 \pm 0.33^{\circ}$ Brix was observed, and, at $892.37 \mathrm{GDD}$, the values was $8.58 \pm 0.37^{\circ} \mathrm{Brix}$ (Fig. $5 \mathrm{~A}$ ).

A TSS increase in apples in the early stages is due to the arrival of sorbitol and sucrose via phloem (Sha et al., 2020). They are used for metabolism, and the surplus accumulates mainly as starch, towards the middle of fruit development (Malladi, 2020). Potentially, sucrose synthase activity can metabolize sucrose to generate the cellulose synthesis necessary for supplying new growth requirements cell wall, which is associated with rapid early growth in apples (Verbančič et al., 2018). In the maturation stage the increase in TSS is explained by the hydrolysis of various structural polysaccharides such as starch, pectins and other oligosaccharides of the cell wall, down to basic monomeric components, which solubilize in the aqueous phase and became part of the juice (Kays, 2004). The main sugars in apple fruits are fructose, sucrose, glucose and sorbitol (Filip et al., 2016). Sorbitol and sucrose stand out since their concentrations increase during fruit development. Towards the ripening stage sucrose is predominant (Sha et al., 2020). Sugars accumulation during ripening is associated with optimal edible quality.

The TTA during the development of the fruit was adjusted to a cubic regression, with increased up to 319.79 GDD where the acidity was $1.20 \pm 0.17 \%$. Later there was a decrease until the harvest, when the fruits presented a TTA of $0.71 \pm 0.03 \%$ (Fig. $5 \mathrm{~B}$ ). Acids are also significantly responsible for flavor with a typical relationship between sugars and acids (Kays, 2004). For the apple 'Anna', this is one of the most important attractions for consumers.

Malic acid is the most abundant organic acid in apples and accumulates during development (Walker and Famiani, 2018). The malate concentration increases gradually during the early development of the fruit and reaches a peak towards the end of cell production during fruit growth (Zhang et al., 2010), as found in this study with a higher TTA at 319.79 GDD (Fig. 5B).

It is assumed that acidity decreases as the ripening process advances, as is reported in three apple
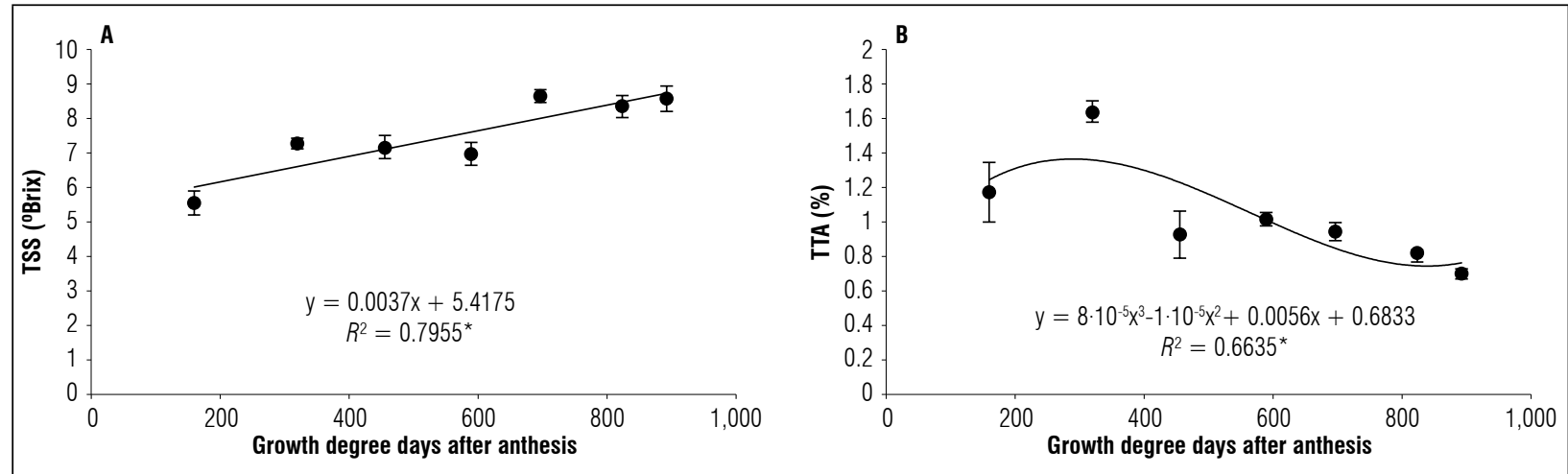

Figure 5. Behavior of A. Total soluble solids and B. Total titratable acidity of apples cv. Anna under conditions in high-altitude tropics. The vertical bars in each mean indicate the standard error $(n=4)$. 
varieties, Gala, Golden Delicious and Princesa (Duran, 2003). The decrease in TTA is due to the use of organic acids during maturation as respiratory substrates and as carbon skeletons for the synthesis of new compounds (Kays, 2004).

\section{CONCLUSIONS}

The dry and fresh weights and the equatorial and polar diameters followed a simple sigmoid pattern. The firmness decreased from 455.39 GDD until 892.37 GDD (100 DAA). The background color index of the epidermis and the pulp showed that the fruits began the growth phase with an intense green color that was lost as a function of development. The TSS had a linear increase with respect to the days after anthesis, and the TTA decreased from 319.79 GDD, coinciding with the stage of greater accumulation of dry weight. The respiratory rate of the fruits decreased continuously during the development of the fruits until the ripening phase.

Conflict of interests: The manuscript was prepared and reviewed with the participation of the authors, who declare that there exists no conflict of interest that puts at risk the validity of the presented results.

\section{BIBLIOGRAPHIC REFERENCES}

Africano-Pérez, K., P. Almanza-Merchán, H. Criollo, A. Herrera, and H.E. Balaguera-López. 2016. Caracterización poscosecha del fruto de durazno [Prunus persica (L.) Batsch] cv. Dorado producido bajo condiciones de trópico alto. Rev. Colomb. Cienc. Hortic. 10(2), 232240. Doi: 10.17584/rcch.2016v10i2.5212

Almanza-Merchán, P., J. Velandia D., and Y. Tovar. 2016. Propiedades fisicoquímicas durante el crecimiento y desarrollo de frutos de lulo (Solanum quitoense Lam.). Rev. Colomb. Cienc. Hortic. 10(2), 222-231. Doi: 10.17584/rcch.2016v10i2.5065

Atay, E., L. Pirlak, and N. Atay. 2010. Determination of fruit growth in some apple varieties. J. Agric. Sci. 16, 1-8. Doi: 10.1501/Tarimbil_0000001115

Balaguera-López, H.E., G. Fischer, and S. Magnitskiy. 2020. Relaciones semilla-fruto en frutos carnosos: Rol de las hormonas. Una revisión. Rev. Colomb. Cienc. Hortic. 14(1), 90-103. Doi: 10.17584/rcch.2020v14i1.10921

Beshir, W.F., V.B.M. Mbong, M.L.A.T.M. Hertog, A.H. Geeraerd, W. Van den Ende, and B.M. Nicolaï. 2017. Dynamic labeling reveals temporal changes in carbon re-allocation within the central metabolism of developing apple fruit. Front. Plant Sci. 8, 1-16. Doi: 10.3389/fpls.2017.01785

Campos, T. 2013. Especies y variedades de hoja caduca en Colombia. pp. 47-67. In: Miranda, D., G. Fischer, and C. Carranza (eds.). Los frutales caducifolios en colombia Situación actual, sistemas de cultivo y plan de desarrollo. Sociedad Colombiana de Ciencias Hortícolas, Bogota.

Casierra-Posada, F., D.I. Hernandez, P. Lüdders, and G. Ebert. 2003. Crecimiento de frutos y ramas de manzano 'Anna' (Malus domestica Borkh) cultivado en los altiplanos colombianos. Agron. Colomb. 21(1-2), 69-73.

Casierra-Posada, F., V. Zapata-Casierra, and J. Cutler. 2017. A comparison of direct and indirect methods for estimating leaf area in peach (Prunus persica) and plum (Prunus salicina) cultivars. Rev. Colomb. Cienc. Hortic. 11(1), 30-38. Doi: 10.17584/rcch.2017v11i1.6143

Castro Neto, M.T. and D.H. Reinhardt. 2003. Relações entre parâmetros de crescimento do fruto de manga cv. Haden. Rev. Bras. Frutic. 25(1), 35-37. Doi: 10.1590/ S0100-29452003000100011

Chaves, B., M.R. Salazar, T. Schmidt, N. Dasgupta, and G. Hoogenboom. 2017. Modeling fruit growth of apple. Acta Hortic. 1160, 335-340. 10.17660/ ActaHortic.2017.1160.48

Costa, F., R. Alba, H. Schouten, V. Soglio, L. Gianfranceschi, S. Serra, S. Musacchi, S. Sansavini, G. Costa, Z. Fei, and J. Giovannoni. 2010. Use of homologous and heterologous gene expression profiling tools to characterize transcription dynamics during apple fruit maturation and ripening. BMC Plant Biol. 10, 229. Doi: 10.1186/1471-2229-10-229

Dash, M., L.K. Johnson, and A. Malladi. 2012. Severe shading reduces early fruit growth in apple by decreasing cell production and expansion. J. Am. Soc. Hortic. Sci. 137, 275-282. Doi: 10.21273/JASHS.137.5.275

Duran, S. 1983. Frigoconservación de la fruta. Editorial AEDOS, Barcelona, Spain.

Fathizadeh, Z., M. Aboonajmi, and S.R. Hassan-Beygi. 2021. Nondestructive methods for determining the firmness of apple fruit flesh. Inf. Process. Agric. Doi: 10.1016/j.inpa.2020.12.002

Filip, M., M. Vlassa, V. Coman, and A. Halmagyi. 2016. Simultaneous determination of glucose, fructose, sucrose and sorbitol in the leaf and fruit peel of different apple cultivars by the HPLC-RI optimized method. Food Chem. 199, 653-659. Doi: 10.1016/j. foodchem.2015.12.060

Fischer, G. 2013 Comportamiento de los frutales caducifolios en el trópico. pp. 31-46. En: Miranda, D., G. Fischer, and C. Carranza (eds.). Los frutales caducifolios en Colombia: Situación actual, sistemas de cultivo y plan de desarrollo. Sociedad Colombiana Ciencias Hortícolas, Bogota. 
Hernández, M.S., O. Martínez, and J.P. Fernández-Trujillo. 2007. Behavior of arazá (Eugenia stipitata Mc Vaugh) fruit quality traits during growth, development and ripening. Sci. Hortic. 111, 220-227. Doi: 10.1016/j. scienta.2006.10.029

Hester, S. and O. Cacho. 2003. Modelling apple orchard systems. Agric. Syst. 77, 137-154. Doi: 10.1016/ S0308-521X(02)00106-3

Iglesias, I., G. Echeverria, and M. Lopez. 2012. Fruit color development, anthocyanin content, standard quality, volatile compound emissions and consumer acceptability of several 'Fuji' apple strains. Sci. Hortic. 137, 138-147. Doi: 10.1016/j.scienta.2012.01.029

Jing, S. and A. Malladi. 2020. Higher growth of the apple (Malus $\times$ domestica Borkh.) fruit cortex is supported by resource intensive metabolism during early development. BMC Plant Biol. 20(75), 2-19. 10.1186/ s12870-020-2280-2

Kays, S. (ed.). 2004. Postharvest biology. Exon Press, Athens, GA.

Lancaster, J.E. 1992. Regulation of skin colour in apples. Crit. Rev. Plant Sci. 10, 487-502. Doi: 10.1080/07352689209382324

Li, M., F. Feng, and L. Cheng. 2012. Expression patterns of genes involved in sugar metabolism and accumulation during apple fruit development. PLoS One 7, e33055. Doi: 10.1371/journal.pone.0033055

Li, M., D. Li, F. Feng, S. Zhang, F. Ma, and L. Cheng. 2016. Proteomic analysis reveals dynamic regulation of fruit development and sugar and acid accumulation in apple. J. Expt. Bot. 67, 5145-5157. Doi: 10.1093/jxb/ erw277

Lin-Wang, K., D. Micheletti, J. Palmer, R. Volz, L. Lozano, R. Espley, R.P. Hellens, D. Chagnè, D.D. Rowan, M. Troggio, I. Iglesias, and A.C. Allan. 2011. High temperature reduces apple fruit colour via modulation of the anthocyanin regulatory complex. Plant Cell Environ. 34, 1176-1190. Doi: 10.1111/j.1365-3040.2011.02316.x

Liu, R., Y. Wang., G. Qin, and S. Tian. 2016. Molecular basis of 1-methylcyclopropene regulating organic acid metabolism in apple fruit during storage. Postharvest Biol. Technol. 117, 57-63. Doi: 10.1016/j. postharvbio.2016.02.001

Magein, H. 1989. Growth and abscission dynamics of 'Cox's Orange Pippin' and 'Golden Delicious' apple fruits. J. Hortic. Sci. 64, 265-273. Doi: 10.1080/14620316.1989.11515954

Malladi, A. 2020. Molecular physiology of fruit growth in apple. pp. 1-42. In: Warrington, I. (ed.). Horticultural reviews. Vol. 47. John Wiley \& Sons, Hoboken, NJ. Doi: 10.1002/9781119625407.ch1

Mariño-González, L.A., C.M. Buitrago, H.E. Balaguera-López, and E. Martínez-Quintero. 2019. Effect of 1-methylcyclopropene and ethylene on the physiology of peach fruits (Prunus persica L.) cv. Dorado during storage. Rev. Colomb. Cienc. Hortic. 13(1), 46-54. Doi: 10.17584/rcch.2019v13i1.8543

Molina-Ochoa, M., J. Vélez-Sánchez, and P. Rodríguez. 2016. Efecto del riego deficitario controlado en las tasas de crecimiento del fruto de pera (Pyrus communis L.), var. Triunfo de Viena. Rev. Colomb. Cienc. Hortic. 9(2), 234-246. Doi: 10.17584/rcch.2015v9i2.4179

Morais, P.L.D., M.R.A. Miranda, L.C.O. Lima, J.D. Alves, R.E. Alves, and J.D. Silva. 2008. Cell wall biochemistry of sapodilla (Manilkara zapota) submitted to 1-methylcyclopropene, Braz. J. Plant Physiol. 20(2), 85-94. Doi: 10.1590/S1677-04202008000200001

Ochoa-Vargas, L.M., H.E. Balaguera-López, G. Ardila-Roa, E.H. Pinzón-Sandoval, and J. Álvarez-Herrera. 2016. Crecimiento y desarrollo del fruto de lulo (Solanum quitoense Lam.) en el municipio de San Antonio del Tequendama (Colombia). Cienc. Tecnol. Agropec. 17(3), 347-359. Doi: 10.21930/rcta.vol17_num3_art:512

Orduz-Ríos, F., K. Suárez-Parra, P. Serrano-Cely, P. Serrano-Agudelo, and N. Forero-Pineda (2020). Evaluation of N-P-K-Ca-Mg dynamics in plum (Prunus salicina Lindl.) var. Horvin under nursery conditions. Rev. Colomb. Cienc. Hortic. 14(3), 334-341. Doi: 10.17584/ rcch.2020v14i3.11941

Puentes, G., L.F. Rodriguez, and L.T. Bermudez. 2008. Análisis de grupo de las empresas productoras de frutales caducifolios del departamento de Boyacá. Agron. Colomb. 26(1), 146-154.

Saei, A., D.S. Tustin, Z. Zamani, A. Talaie, and A.J. Hall. 2011. Cropping effects on the loss of apple fruit firmness during storage: The relationship between texture retention and fruit dry matter concentration. Sci. Hortic. 130, 256-265. Doi: 10.1016/j.scienta.2011.07.008

Sha, J., F. Wang, X. Xu, O. Chen, Z. Zhu, and Y. Jiang. 2020. Studies on the translocation characteristics of ${ }^{13} \mathrm{C}$-photoassimilates to fruit during the fruit development stage in 'Fuji' apple. Plant Physiol. Biochem. 154, 636-645. Doi: 10.1016/j.plaphy.2020.06.044

Verbančič, J., J.E. Lunn, M. Stitt, and S. Persson. 2018. Carbon supply and the regulation of cell wall synthesis. Mol. Plant. 11, 75-94. Doi: 10.1016/j.molp.2017.10.004

Walker, R.P. and F. Famiani. 2018. Organic acids in fruits: metabolism, functions and contents. Hortic. Rev. 46, 371-430. Doi: 10.1002/9781119431077.ch8

Wulfsohn, D., F. Aravena, C. Potin, I., Zamora, and M. García-Finana. 2012. Multilevel systematic sampling to estimate total fruit number for yield forecasts. Prec. Agric. 13, 256-275. Doi: 10.1007/s11119-011-9245-2

Yao, J.L., J. Xu, A. Cornille, S. Tomes, S. Karunairetnam, Z. Luo, H. Bassett, C. Whitworth, J. Rees-George, C. Ranatunga, A. Snirc, R. Crowhurst, N. de Silva, B. Warren, C. Deng, S. Kumar, D. Chagné, V.G.M. Bus, R.K. Volz, E.H.A. Rikkerink, S.E. Gardiner, T. Giraud, R. MacDiarmid, and A.P. Gleave. 2015. A microRNA 
allele that emerged prior to apple domestication may underlie fruit size evolution. Plant J. 84, 417-427. Doi: 10.1111/tpj.13021

Yuri, J.A., J. Gonzalez, J. Verdugo, and A. del Pozo. 2011. Responses of fruit growth, quality, and productivity to crop load in apple cv. Ultra Red Gala/ MM111. Sci. Hortic. 127, 305-312. Doi: 10.1016/j. scienta.2010.10.021

Zadravec, P., R. Veberic, F. Stampar, K. Elerc, and V. Schmitzer. 2013. Fruit size prediction of four apple cultivars: Accuracy and timing. Sci. Hortic. 160, 177181. Doi: $10.1016 /$ j.scienta.2013.05.046

Zhang, Y., L. Zheng., M. Li., X. Deng, and J. Zhang. 2015. Predicting apple sugar content based on spectral characteristics of Apple tree leaf in different phenological phases. Comput. Electron. Agr. 112, 20-27. Doi: 10.1016/j.compag.2015.01.006

Zhang, Y., P. Li, and L. Cheng. 2010. Developmental changes of carbohydrates, organic acids, amino acids, and phenolic compounds in 'Honeycrisp' apple flesh. Food Chem. 123, 1013-1018. Doi: 10.1016/j. foodchem.2010.05.053

Zhu, L., C. Yang, Y. You, W. Liang, N. Wang, F. Ma, and C. Li. 2019. Validation of reference genes for qRTPCR analysis in peel and flesh of six apple cultivars (Malus domestica) at diverse stages of fruit development. Sci. Hortic. 244, 165-171. Doi: 10.1016/j. scienta.2018.09.033 